Article

\title{
Services Sector Export in Europe
}

\author{
Anatolijs Prohorovs ${ }^{1}$ and Marina Solesvik ${ }^{2, *(1)}$ \\ 1 Department of Economy and Finance, Meza Street, RISEBA University of Business, \\ Arts and Technology (RISEBA), LV-1048 Riga, Latvia; anatolijs.prohorovs@gmail.com \\ 2 Nord University Business School, Nord University, Universitetsaleen, 8049 Bodø, Norway \\ * Correspondence: marina.solesvik@hvl.no; Tel.: +47-481-33-882
}

Received: 31 October 2018; Accepted: 30 November 2018; Published: 4 December 2018

\begin{abstract}
In this paper, we consider the changes that occurred in the service exports of thirty-eight European countries in the period of 2005-2016. We have found that the existing world trend related to the growth of service exports is also present in Europe. However, the trend of the service exports' share growth in the general volume of export is not common for all European countries. We found that higher growth rates are observed in European countries with lower levels of GDP per capita. We also discovered the presence of a strong positive correlation between growth in service exports and GDP growth, as well as between growth in service exports and GDP per capita. We also found that there is a linear correlation between the growth of service exports and the growth of GDP per capita, as well as between the growth in service exports and GDP growth. The data obtained allowed us to conclude that European countries, categorized as "Innovation Leaders" in accordance with the European Innovation Scoreboard, are not the leading countries in Europe with regard to the rates of service export growth. We also discovered that service exports in Europe are less sensitive to adverse macroeconomic effects than goods exports.
\end{abstract}

Keywords: export of services; international trade in services; indicators of trade in services; international trade; Europe

\section{Introduction}

The results of some previous research [1,2] show that there is currently a macroeconomic shift towards services. The services sector is the most rapidly growing sector of the world economy, and the export of services is becoming an increasingly important component in a country's export portfolio [2-5]. According to the findings of Loungani et al. [5], which they obtained by analyzing data on the export structure of 192 countries, the share of services in 2014 constituted more than 20 per cent of total exports, while in 1970 it was only about 9 per cent. According to United Nations Conference on Trade and Development (UNCTAD) [6], the share of services exports, out of the total number of exports of goods and services had increased from 24 per cent in 2005 to 28 per cent in 2016 in developed economies, and from 14 to 17 per cent in developing economies.

The findings of the global research carried out by UNCTAD [7] indicate that only during the last decade, service exports, for developed countries, began showing a strong and increasing impact on the overall GDP growth. Furthermore, the correlation analysis [7] also shows that service exports have a positive impact on GDP growth in developing countries. Previous research, based on the analysis of data from 125 countries, also discovered statistically significant relations between service exports and GDP per capita for 2007 [8].

According to UNCTAD [6], service exports have been more resilient than goods exports. Following Loungani et al. [5], Europe is still leading in the export of services. Five European countries belong to the top ten service exporters in the world. United Kingdom, Germany and France possess the second, 
third and fourth places, and the Netherlands possesses sixth place in terms of the volume of service exports [6].

The existing scientific literature $[9,10]$ shows that the service exports in European countries is much more sustainable to economic crises than the export of goods. However, these conclusions were only made based on the data from two European countries (Lithuania and Belgium), not the whole population of European countries.

Though European countries have a dominating position in terms of service exports, the existing literature has not yet answered the following research questions: What is the share of service exports in the general volume of exports from European countries? What are the dynamics of the growth of service exports in general, compared to the growth of goods exports? Do service exports grow faster that goods export in all European countries? Have service exports grown faster than goods exports in European countries with the higher (or lower) level of economic development, GDP level and GDP per capita level? Is there any correlation between the growth of service exports, GDP and GDP per capita? In the scientific literature we have also not found the answer to the question of whether service exports, especially services based on innovation technologies provide the exporting countries higher rates of service exports. In our study, we attempt to answer these questions.

In order to fill this gap in the knowledge base, we use an analysis of statistical data on thirty-eight European countries to answer the research question of this study. In order to answer the research questions, we set the following tasks:

1. To conduct an analysis of service export growth rates in Europe.

2. To determine the differences in the changes in service export growth rates in European countries with different levels of economic development.

3. To identify the relationship of growth in GDP and GDP per capita rates on service export growth.

4. To conduct an analysis of changes in the share of service exports for different groups of countries in Europe.

5. To establish whether the leaders in service export growth are innovation leaders, to determine the variance of service export growth in 2016 compared to 2005 depending on the level of innovative development of the country.

6. To determine the sensitivity of service exports compared to goods exports to financial crises.

The analysis carried out in this paper shows the changes in volume and growth dynamics of service exports in thirty-eight European countries. Our novel contribution is the exploration of these changes in service export dynamics and the volume depending on the country's level of economic development, GDP, and GDP per capita. We also concluded that those European countries that are innovation leaders have the lowest growth in service exports. This finding can start a scientific discussion related to whether the level of innovation development of a country influences the growth dynamics of service exports. The results of this study also confirm that in Europe, just like in the world in general, service exports are more resistant to the negative influence of the financial crisis than goods exports.

The paper is organized as follows. First, we analyze the existing literature. Then we describe the research methodology and data. Further on, we present the results and discuss the findings. The final part of the paper presents conclusions, limitations and recommendations for further research.

\section{Literature Review}

\subsection{The Main Reasons for Service Exports Growth}

In the 21st century, services are the basis and the driver of economic growth in all spheres of business activity [11]. Services play the key role in ensuring the sustainable economic growth of various countries [12]. Services are also the key factor determining international competitiveness [13]. The development of services is the main catalyst for economic transformations [14]. The expansion 
of service markets is the decisive factor for future economic development and value creation in Europe [15]. Infrastructure services play a major role in the economic and structural development of both developed and developing countries and make a significant contribution to all the sectors of the economy [13]. Gallego et al. [16] find that services are no longer secondary instruments in the value chain, as services may, for instance, add value in product design, business management, procurement in global markets, and support to a customer's participation in value creation.

A growing volume of trade in services remains imperative for the diversification and competitiveness of countries with various levels of development [17,18]. Gallagher [4] points out that services increasingly form the main part of national economies in both the developed and developing world and that trade in services may become the driving force of sustainable development in developing countries. Furthermore, countries with higher service output growth experienced higher overall economic growth [8]. Developing countries in the early stage of economic development may have a large share of services in the economy [19]. For some developing countries, services have become more important in stimulating GDP growth than manufacturing [8].

Services are a major factor in determining the competitiveness of all enterprises in countries with an open economy, irrespective of the type of business activity and presence or absence of competitive advantages [20]. According to Uppenberg and Strauss [1], there is currently a macroeconomic shift towards services; global rankings of leading enterprises, such as the Fortune 500, comprise more service companies than in previous decades. In some cases, manufacturing firms are transforming into companies that mainly provide services. Companies exporting services are, as a rule, smaller in size than manufacturing companies, but they are more efficient than exporters of goods, and that, in its turn, increases their competitiveness [21]. The findings of [22] also attest the higher efficiency of companies exporting services compared to manufacturing companies.

The results of the previous research indicate that researchers agree that the value of services in general and the exports of services in particular in the development of the economy is increasing. Researchers also note that services play an important role in determining the efficiency and competitiveness of companies, as well as international competitiveness.

\subsection{Growth in Service Exports}

Services are the most rapidly growing sector of the world economy; at the end of the 1990s and the beginning of the 2000s, trade in services was growing more rapidly than trade in goods [3]. The export of services in the world economy is growing faster than the export of goods [4]. The export of services is becoming an increasingly important component in a country's export portfolio [5]. Trends in international trade in services show growth in the volume and share of services [2]. Moreover, the volume of services with high added value will keep growing [9]. According to data from the World Trade Organization [23], in the previous two decades global trade in commercial services has increased on average by 8 percent annually. At the same time, developing countries demonstrated higher rates of service export growth [24]. For some countries, services can become the drivers of export growth [20]. Moreover, developing countries have become important providers of services for developed countries [25]. According to UNCTAD [7] data, the export of services has a positive impact on GDP growth in developing countries. Furthermore, according to this data, this impact, as in the case of developed countries, is becoming more pronounced and statistically significant in the long-term rather than the short-term perspective. According to Loungani et al. [5], a country's experience in the field of export services depends not only on its development stage and income level, but also on its geographic location.

Summarizing this part of the literature review, we note that researchers find that service exports grow faster than goods exports, and that developing countries demonstrate higher levels of service exports growth. At the same time, the experience of countries in the field of export services depends not only on the level of development and level of income, but also on its geographical location. 


\subsection{Export of Services in Countries with Different Levels of Economic Development}

Service sector growth is closely connected with a decrease in poverty [26]. The GDP per capita index is one of the factors stimulating the development of services [27]. The export of services is linked to higher GDP per capita rates [5]. Furthermore, the share of services in GDP and employment rates grows alongside the income per capita [28]. According to UNCTAD [7] data, in developing countries the correlation between service exports and GDP growth is weaker than in developed countries. In the countries with the lowest income, services generate about 35 per cent of GDP. Notably, in OECD countries, services generate more than 70 per cent of the national income and employment. According to UNCTAD [6] data, in the 1980-2015 period, the share of services in GDP increased in all groups of countries in terms of their income, from 61 to 76 per cent in developed countries and from 42 to 55 per cent in developing countries. In 2015, it was mainly developed economies that were the largest global exporters and importers of services, for example, in Europe it was Germany, Great Britain and Ireland. In 2011, services ensured 44 per cent of the added value in the total exports of developed countries and 32 per cent in developing countries. However, developing countries showed higher rates of service export growth [3]. Deindustrialization was implemented in developing countries as a result of globalization and an increase in the volume of international trade may lead to significant growth in the volume of services in developing countries [19].

Summarizing, it can be stated that researchers agree that in developing countries the share of services in GDP is lower than in developed countries, and the growth rate of exports of services is higher than in developed countries. At the same time, GDP per capita is one of the factors stimulating the development of services.

\subsection{Impact of the Innovation Economy and Modern Technologies on Service Export Growth}

Trade in intermediate services has been a lot more dynamic than trade in goods, as growth in trade in intermediate services is closely connected with the development of the knowledge-based economy [29] (Rodriguez et al., 2018). Technological innovations increasingly make services exportable at low costs. The globalization of services provides new opportunities for the development of service exports for countries with different levels of economic development [5]. Furthermore, the export of services stimulates innovation due to the increase in return on investment [9].

Notably, Information and Communication Technologies (ICT) has become one of the main driving factors in the development of the service sector, transforming traditional services, generating a wide range of new services, and changing the channels of their distribution [30]. Increasingly, services can be traded between sellers and buyers on the global level almost immediately via satellite networks [5]. The Internet and other network technology systems, such as mobile phones, big data and artificial intelligence, ensure technical changes in production methods and business processes, which promotes the export of technological services.

According to the World Trade Organization [23], some groups of services, such as ICT and financial services, often surpass the average growth rates of service exports. Furthermore, Loungani et al. [5] note that services, such as telecommunications, computer and information services now constitute one of the most dynamically developing sectors ensuring growth in service exports.

Service export share growth was promoted by the international outsourcing of services, which grew significantly as a result of the dramatic decrease in telecommunication costs, wider access to the Internet and ubiquitous use of computers [25]. Additionally, geographic distance causes considerably less trade costs online than offline [31].

Summarizing the literature review in this subsection, we can notice that researchers agree that the growth in trade in intermediate services is closely connected with the development of the knowledge-based economy. In addition, technological innovations can reduce the prices of services and make a number of services exportable. The growth rate of exports of some services based on innovation exceeds the growth rates of exports of other services. 


\subsection{Resilience of Service Exports to Crises}

Ariu [10] points out that in the period of the global financial crisis, in the interval between the third quarter of 2008 and the second quarter of 2009, export trade in services was practically unaffected by the crisis. Similarly, trade in services survived the financial crisis much more easily than trade in goods [5]. Services with the highest added value, for instance, ICT services, are more active during economic stagnation compared to services with low added value, which are much more sensitive to economic fluctuations [9]. The volume of trade in essential services in the period of the global financial crisis of 2008-2009 continued to grow [32]. Only transportation services faced a considerable decrease in volume in the period of the global financial crisis [33]. Researchers agree that export trade in services is less sensitive to economic crises [34].

\section{Methodology and Data}

We used data from the European Union (EUROPA—Countries/European Union) [35] to determine the countries that can be classified as European. This list includes 50 countries. The analysis of service exports of not only EU countries, but also of a wider range of European countries, allowed us, firstly, to increase the number of countries analyzed and therefore increase the reliability of the research and secondly, to identify the differences and tendencies in the export of services not only among the countries of the EU-15 and "New Europe"(EU-13), but also among the countries categorized as "Economies in Transition".

The Eurostat database does not include data on the export of services and export of goods for all European countries. Therefore, we used data on the export of services and export of goods from the International Trade Centre UNCTAD/WTO [36] in this research. The International Trade Centre UNCTAD/WTO Database [36] does not provide data on the export of goods/services for some European countries, however it provides data on the export of services for some countries for only some years. For this reason, the selection of countries for analysis was performed based on the possibility to pick the maximum number of countries with available data covering a relatively long period. An analysis of the data on the export of services was conducted considering 38 European countries in the twelve-year period of 2005 up to and including 2016.

As a result of selection based on the availability of service export data, one of the EU-15 countries-the Netherlands-was not included in the sample and neither were two of the thirteen countries of "New Europe": Bulgaria and Cyprus. Correspondingly, the research presents data on 25 of the $28 \mathrm{EU}$ member states, which represents 89.3 percent of the EU countries. The analysis includes data on three non-EU countries that are classified as "Other European Countries"-Iceland, Norway, and Switzerland - which, in accordance with the United Nations Country Classification [37], belong to the category "Developed Economies". The remaining ten countries analyzed in the research are classified as "Other European Countries" and, in accordance with the United Nations Country Classification [37], belong to the category "Economies in Transition".

Some European non-EU countries were not considered in the analysis due to the lack of data on their service exports, such as Andorra, Liechtenstein, Monaco, San Marino, Vatican, Kosovo, Macedonia, Serbia, and Montenegro.

The indicators for service and goods export growth were calculated in the following way: the indicator for the year 2005 was deducted from the indicator for the year 2016 and the result was divided by the indicator for the year 2005. The aggregate share of service exports was calculated as a proportion of the aggregate service exports in the total exports of European countries.

The average annual growth in service exports, goods exports and aggregate exports was calculated as a geometric mean. To identify the relationship of growth in GDP and GDP per capita rates on service export growth we conducted a correlation analysis. To identify a linear relationship between GDP growth and growth in service exports, as well as GDP per capita growth and growth in service exports, a regression analysis was conducted. Comparing the rates of service export growth in European countries with different GDP per capita indicators, the GDP per capita index for 2016 was used. 
In order to determine the growth trends of service exports from various European countries, the countries examined in the study were divided into four quartiles. The grouping of countries by quartile was carried out based on the ranking of all countries by absolute indicators for service export growth rate from 2005 to 2016 following the principle "from small to big", that is, the countries with lower absolute indicators for service export growth rate were grouped into the first quartile. The same principle was used when dividing countries into the first and second half.

We used the data from the European Innovation Scoreboard [38] to establish the correlation between the share of service exports and the level of innovative development of European countries. 30 of the 38 countries considered in the present research were represented in the European Innovation Scoreboard [38], whereas countries such as Albania, Armenia, Azerbaijan, Belarus, Bosnia and Herzegovina, Georgia, Moldova, and Russia were not covered. Thus, in order to determine the differences in service export growth depending on the level of innovative development, a dispersion analysis was conducted for the 30 countries listed in the European Innovation Scoreboard [38]. To determine the variance of service export growth in 2016 compared to 2005 among country groups-“Innovation Leaders" (e.g., Sweden, Finland, Denmark, the UK), "Strong Innovators" (France, Germany, Austria), “Moderate Innovators" (e.g., Spain, Italy, Poland, the Baltic countries), "Modest Innovators" (Bulgaria and Romania)—we created a box plot of service export growth in the period of 2005-2016.

To compare the sensitivity of service exports to the financial crisis, the study examined how indicators of service exports changed in Europe compared with products exported before the financial crisis, as well as during and after the financial crisis of 2008-2009.

The UNCTAD data [6] was used to calculate the share of service exports in the global export volume.

\section{Research and Discussion}

\subsection{Growth of Service Exports in European Countries}

To assess the changes in the indicators for service exports, in the first subsection of the Research and Discussion section we have considered the rates of service export growth in the analyzed countries and compared them with the rates of goods export growth. To determine the tendencies in service export growth in various European countries we divided all the countries into four quartiles, having ranked the countries based on their rates of service export growth in an ascending order, i.e., from lowest to highest (the changes in the indicators for service exports by country are presented in Appendix A, and the changes in the indicators for goods exports by country are presented in Appendix B). The values of growth rates of service exports and goods exports are given in Table 1 . From 2005 to 2016, service exports in European countries increased by $60.1 \%$. In the same period, goods exports increased by $33.7 \%$. The data obtained on the prominent growth rates of service exports in Europe from 2005-2016 is in line with the data on global tendencies regarding the prominent growth rates of service exports [3-5,9].

Table 1. Growth in service exports and goods exports in Europe from 2005-2016 ${ }^{1}$.

\begin{tabular}{ccccc}
\hline $\begin{array}{c}\text { Total Growth and Growth in } \\
\begin{array}{c}\text { Service Exports by Quartile/Service } \\
\text { Export Growth Rates }\end{array}\end{array}$ & $\begin{array}{c}\text { The First and the Last } \\
\text { Indicator Value of Service } \\
\text { Export Growth in a Quartile, \% }\end{array}$ & $\begin{array}{c}\text { Service Export } \\
\text { Growth, \% }\end{array}$ & $\begin{array}{c}\text { Goods Export } \\
\text { Growth, \% }\end{array}$ & $\begin{array}{c}\text { Ratio of Service Export } \\
\text { Growth to Goods } \\
\text { Export Growth, Times }\end{array}$ \\
\hline $\begin{array}{c}\text { Total growth in service and goods } \\
\text { exports in 38 European countries }\end{array}$ & - & 60.1 & 33.7 & 1.78 \\
First quartile & From -18.0 to 37.9 & 22.1 & 33.7 & 0.66 \\
Second quartile & From 39.3 to 76.1 & 55.0 & 29.5 & 1.86 \\
Third quartile & From 80.7 to 134.7 & 98.3 & 37.1 & 2.65 \\
Fourth quartile & From 143.6 to 490 & 167.0 & 65.5 & 2.55 \\
\hline
\end{tabular}

${ }^{1}$ Data compiled by the authors based on data from the International Trade Centre UNCTAD/WTO [36], from the respective countries. 
From 2005 to 2016, the average annual growth in service exports amounted to $4.4 \%$. The average annual growth in goods exports was $2.7 \%$. The annual growth in service exports was 1.7 percentage points higher than the annual growth in goods exports. Based on the data obtained, we can conclude that in the period of 2005-2016 the aggregate growth in service exports in Europe was 1.78 times higher than the growth in goods exports. We also determined that in 25 out of 38 European countries in the period of 2005-2016 the rates of service export growth were higher than the rates of goods export growth.

The highest values of service export growth were recorded in Azerbaijan, Georgia, and Armenia-490\%, $356.2 \%$ and $274.3 \%$, respectively. Among the countries of Western and Northern Europe, the highest rates of service export growth were demonstrated in Ireland, Iceland, and Luxembourg-159.2\%, $143.6 \%$ and $134 \%$, respectively.

The data presented testifies that there are significant differences in the growth rates of service exports even among the countries with the highest values of service export growth. The indicators for service export growth of the first three countries, namely, Azerbaijan, Georgia, and Armenia, were 2.6 times higher than those of the three countries of Western and Northern Europe-Ireland, Iceland, and Luxembourg - which demonstrated the highest growth in service exports from 2005 to 2016. The data we obtained correlate with the results of Mattoo et al. [3] attesting that developing countries showed higher service export growth rates. The lowest rates of service export growth in the period considered were demonstrated by Norway, Ukraine, and Italy $-22 \%, 18.7 \%$ and $10.2 \%$, respectively. At the same time, Greece's service exports decreased by $18 \%$. The countries grouped into the first quartile showed lower rates of service export growth than goods export growth. The data obtained demonstrates considerable differences in the rates of service export growth in European countries.

\subsection{Export of Services in European Countries with Different Levels of Economic Development}

To determine whether there is any difference in the rates of service export growth depending on the level of economic development, we grouped all the analyzed countries into categories according to the United Nations Country Classification [37]. We also grouped all considered countries into four quartiles and two halves based on their service export growth rates in descending order. Furthermore, we analyzed how many countries may be grouped into each quartile and into the first and second half (Table 2), according to the United Nations Country Classification.

Table 2. Grouping of European countries by the growth rate indicator for service exports from 2005-2016 into quartiles and halves in accordance with the United Nations Country Classification ${ }^{1}$.

\begin{tabular}{|c|c|c|c|c|c|c|}
\hline $\begin{array}{c}\text { Quartile and Half/Group } \\
\text { of Countries }\end{array}$ & $\begin{array}{l}\text { First Quartile } \\
\text { (9 Countries) }\end{array}$ & $\begin{array}{l}\text { Second Quartile } \\
\text { (10 Countries) }\end{array}$ & First Half & $\begin{array}{l}\text { Third Quartile } \\
\text { (10 Countries) }\end{array}$ & $\begin{array}{l}\text { Fourth Quartile } \\
\text { (9 Countries) }\end{array}$ & Second Half \\
\hline Economies in transition & 1 & 2 & 3 & 2 & 4 & 6 \\
\hline New EU member states (EU-13) & 2 & 2 & 4 & 4 & 3 & 7 \\
\hline European Union (EU-15) & 3 & 2 & 5 & 4 & 1 & 5 \\
\hline Other Europe & 2 & 1 & 3 & 0 & 1 & 1 \\
\hline Major developed economies (G7) ${ }^{2}$ & 1 & 3 & 4 & 0 & 0 & 0 \\
\hline
\end{tabular}

${ }^{1}$ Data compiled by the authors based on data from the International Trade Centre UNCTAD/WTO [36] and the United Nations [37], World Economic Situation and Prospects, Country Classification from the respective countries. ${ }^{2}$ If the country is simultaneously in the European Union group (EU-15) and in the Major developed economies (G7) group, then in this table the country is taken into account in the line Major developed economies (G7).

As shown in Table 2, among the countries grouped into the fourth quartile, the largest number of countries-four-belong to the category "Economies in Transition", three countries belong to the category "New EU Member States", one country belongs to the category EU-15 and none belong to the group of countries "Major Developed Economies" (G7). Compared to the fourth quartile, in the second and third quartile, the number of countries categorized as "Economies in Transition" decreased to two, while in the first quartile they decreased to one country. There are three countries less belonging to the group "New EU Member States" in the first half than in the second half. No country 
categorized as a "Major Developed Economy" (G7) appeared in the second half, while there were four countries in the first half. Three out of four countries categorized as "Other Europe", including Norway, Iceland, and Switzerland, which belong to the developed countries according to their level of economic development, were also grouped into the first half.

Having considered service export growth in European countries grouped by quartiles and halves, we may conclude that the highest rates of service export growth in the period of 2005-2016 were characteristic of the countries belonging to the category "Economies in Transition". Countries belonging to the category "New EU Member States" also demonstrated high service export growth rates. Based on the results of the analysis, it can be concluded that the highest rates of service export growth are characteristic of countries with lower levels of economic development. The data obtained correlates with the research results of Mattoo et al. [3] and Rodrik [19].

We also calculated the average GDP growth from 2005 to 2016 for each quartile. The GDP growth amounted to $17 \%$ in the first quartile, $35 \%$ in the second, $49 \%$ in the third and $82 \%$ in the fourth. That is, the European countries that demonstrated the highest service export growth also demonstrated higher GDP growth.

To establish whether there is any correlation between growth in service exports and GDP growth, we created a scatter plot of GDP growth and service export growth (Figure 1).

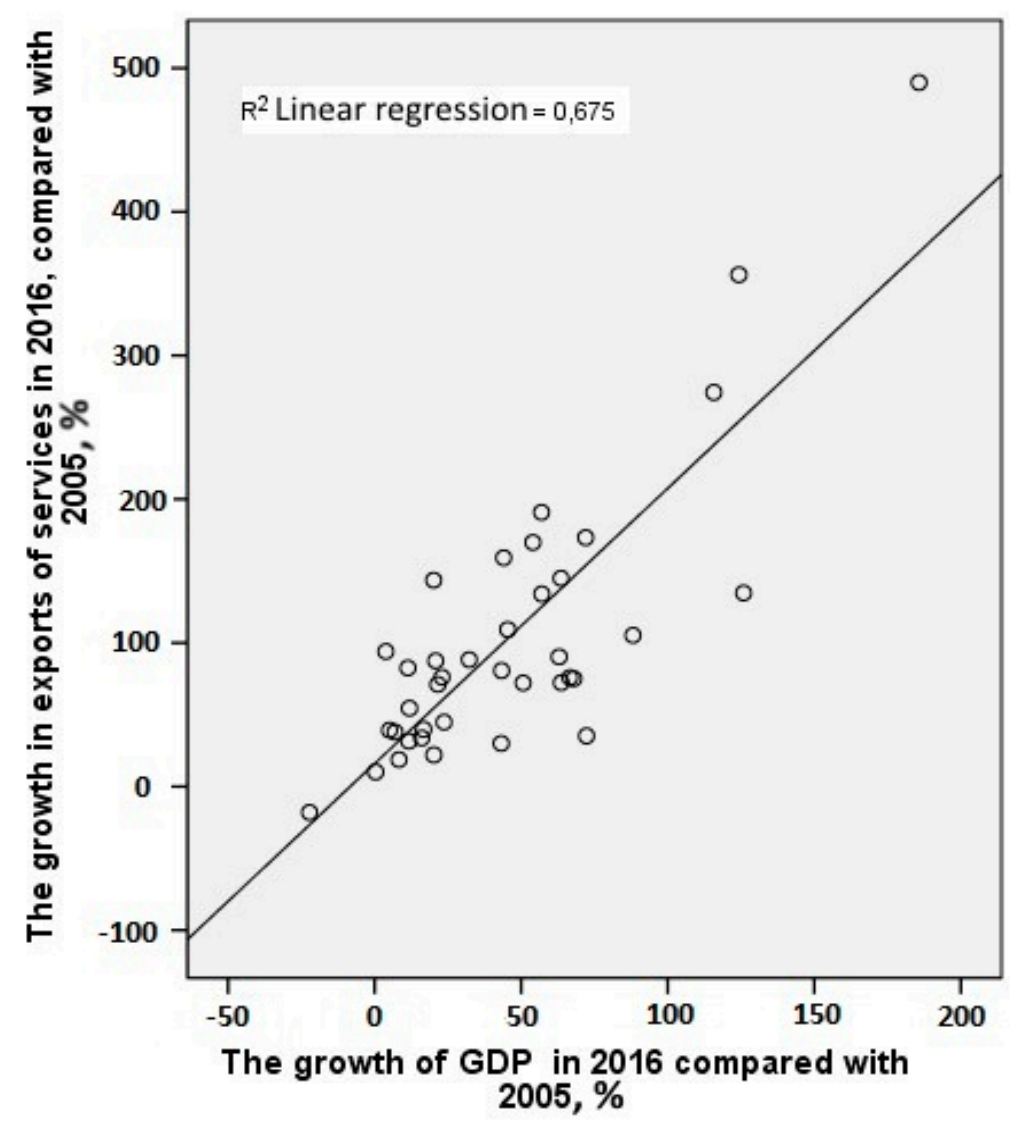

Figure 1. Correlation scatter plot of GDP growth rate and service export growth rate.

A correlation analysis was conducted to estimate the correlation between the rates of GDP growth and service export growth from 2005-2016. The results of the correlation analysis demonstrate that the Pearson correlation coefficient $\mathrm{R}=0.822$ is statistically significant $(p$-level $<0.001)$. This attests the presence of a strong positive correlation between growth in service exports and GDP growth. It may be concluded that the countries with higher service export growth rates demonstrate higher GDP growth. A regression analysis was conducted to establish a linear dependence between GDP growth and service export growth. 
The outcomes of the regression analysis of growth in service exports and GDP growth from 2005-2016 resulted in the following regression Equation:

$$
\mathrm{y}_{\text {service_exports_growth }}=1.916 * \mathrm{~T}_{\mathrm{GDP} \_ \text {growth }}+0.160
$$

The conducted regression analysis demonstrates that the growth in GDP of $1 \%$ on average corresponds to growth in service exports of $1.96 \%$.

Considering the results of the regression analysis, this model is statistically significant $(\mathrm{F}=74.759)$. $67.5 \%$ of service export growth is influenced by GDP growth $\left(R^{2}=0.675\right)$ and other factors are responsible for the remaining $32.5 \%$. The results of the regression analysis are presented in Appendix C.

\subsection{Export of Services in European Countries with Different GDP per Capita}

To determine whether there were any differences in the rates of service export growth depending on the index of GDP per capita in the countries considered from 2005-2016, we grouped European countries by annual GDP per capita in 2016 in accordance with the International Monetary Fund [39] classification. The countries were grouped into four quartiles and two halves based on their service export growth rates in an ascending order (Table 3). This means that the countries with the lowest rates of service export growth were grouped into the first quartile. As a result of the analysis we determined that GDP per capita was lower than 2500 USD in two countries, 2500-10,000 USD in eight countries, $10,000$ to 25,000 USD in twelve countries, and more than 25,000 USD in sixteen countries ( $42.1 \%)$.

Table 3. Grouping of European countries by rate of service export growth in the period of 2005-2016 into quartiles and halves according to the GDP per capita indicator ${ }^{1}$.

\begin{tabular}{|c|c|c|c|c|c|c|}
\hline $\begin{array}{c}\text { Quartile and a Half/GDP } \\
\text { per Capita, USD }\end{array}$ & $\begin{array}{l}\text { First Quartile } \\
\text { (9 Countries) }\end{array}$ & $\begin{array}{l}\text { Second Quartile } \\
\text { (10 Countries) }\end{array}$ & First Half & $\begin{array}{l}\text { Third Quartile } \\
\text { (10 Countries) }\end{array}$ & $\begin{array}{l}\text { Fourth Quartile } \\
\text { (9 Countries) }\end{array}$ & Second Half \\
\hline 25,000 or more & 4 & 6 & 10 & 3 & 3 & 6 \\
\hline $10,000-25,000$ & 4 & 2 & 6 & 4 & 2 & 6 \\
\hline $2500-10,000$ & 0 & 2 & 2 & 2 & 4 & 6 \\
\hline $500-2500$ & 1 & 0 & 1 & 1 & 0 & 1 \\
\hline
\end{tabular}

${ }^{1}$ Data compiled by the authors based on data from the International Trade Centre UNCTAD/WTO [36] and the International Monetary Fund [39], GDP per capita indicators.

As shown in Table 3, in the fourth quartile the largest number of countries reported GDP per capita of 2500-10,000 USD. We also grouped the analyzed countries into two halves with 19 countries each. The countries with the highest rates of service export growth were included in the second half. In the second half, which demonstrated higher service export growth rates, there were six countries with GDP per capita of more than 25,000 USD, and in the first half there were ten countries with such level of GDP. There were seven counties with GDP per capita less than 10,000 USD in second half, and only three countries in the first half.

Based on the results of the analysis, we may conclude that higher rates of service export growth in European countries in most cases were demonstrated by countries with a lower index of GDP per capita. Our conclusion, that the rates of service export growth in Europe are higher in countries with a lower GDP per capita index, is in line with the findings of Mattoo et al. [3] which show that countries with a lower level of economic development demonstrate higher rates of service export growth. However, based on an analysis of the export structure of 192 countries, Loungani et al. [5] find that the export of services is associated with higher GDP per capita. They note that a country's experience in providing export services depends not only on its development and income level, but also on the geographical location of the region. This is why the differences in the results we obtained regarding the higher rates of service export growth in countries with lower GDP per capita and the contrasting results of Loungani et al. [5] may be explained by the specifics of the geographic location of some European countries, and, possibly, of the entire European region as a whole. 
In order to determine whether there is any correlation between GDP per capita growth and growth in service exports in the period of 2005-2016, we conducted a correlation analysis. Figure 2 presents a correlation scatter plot, which clearly demonstrates that there is a certain correspondence between GDP per capita growth and the growth in service exports.

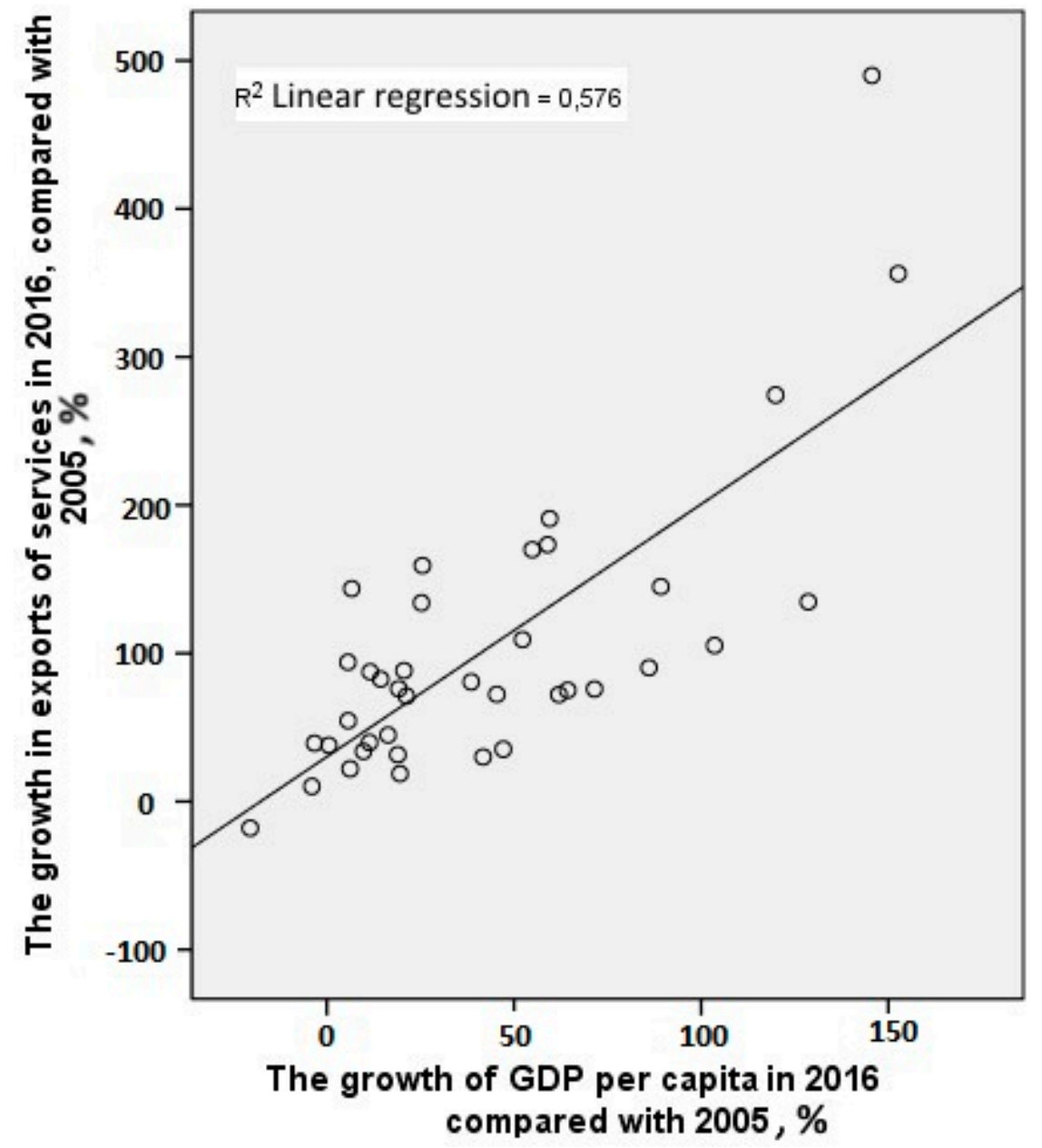

Figure 2. Correlation scatter plot of growth in GDP per capita and service export growth.

A correlation analysis was conducted to estimate the correlation between growth in GDP per capita and service export growth from 2005-2016.

The results of the correlation analysis demonstrate that the Pearson correlation coefficient $R=0.759$ is statistically significant $(p$-level $<0.001)$. This attests that there is a strong positive correlation between the growth in service exports and GDP per capita growth.

As a result of the regression analysis (Appendix C), a linear dependence of the growth of exports of services on the growth of GDP per capita was revealed. A linear dependence of service export growth on GDP per capita growth was detected as a result of the conducted regression analysis.

The regression Equation is as follows:

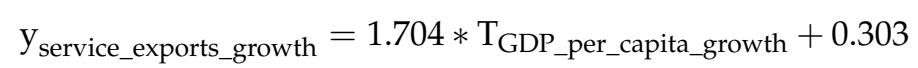

It follows from the regression equation that an increase in the GDP per capita growth rate of $1 \%$ corresponds to the average growth in service exports of $1.704 \%$.

Considering the results of the regression analysis, this model is statistically significant $(\mathrm{F}=48.83)$. The results of the analysis attest that $57.6 \%$ of service export growth is determined by growth in GDP per capita $\left(\mathrm{R}^{2}=0.576\right)$ and $42.4 \%$ is explained by other factors. 


\subsection{Share of Services in European Exports}

Along with changes in rates of service export growth, countries display changes in the rates of goods export growth. For this reason, absolute values of service export growth alone do not allow one to identify tendencies in the change in the share of service exports in total exports. Thus, in this subsection we analyse the changes in the share of services in total exports in the European countries under discussion. We also consider the number of European countries where the share of service exports of the total number of exports grew in the period of 2005-2016. The changes in the share of service exports in European countries are presented in Figure 3.

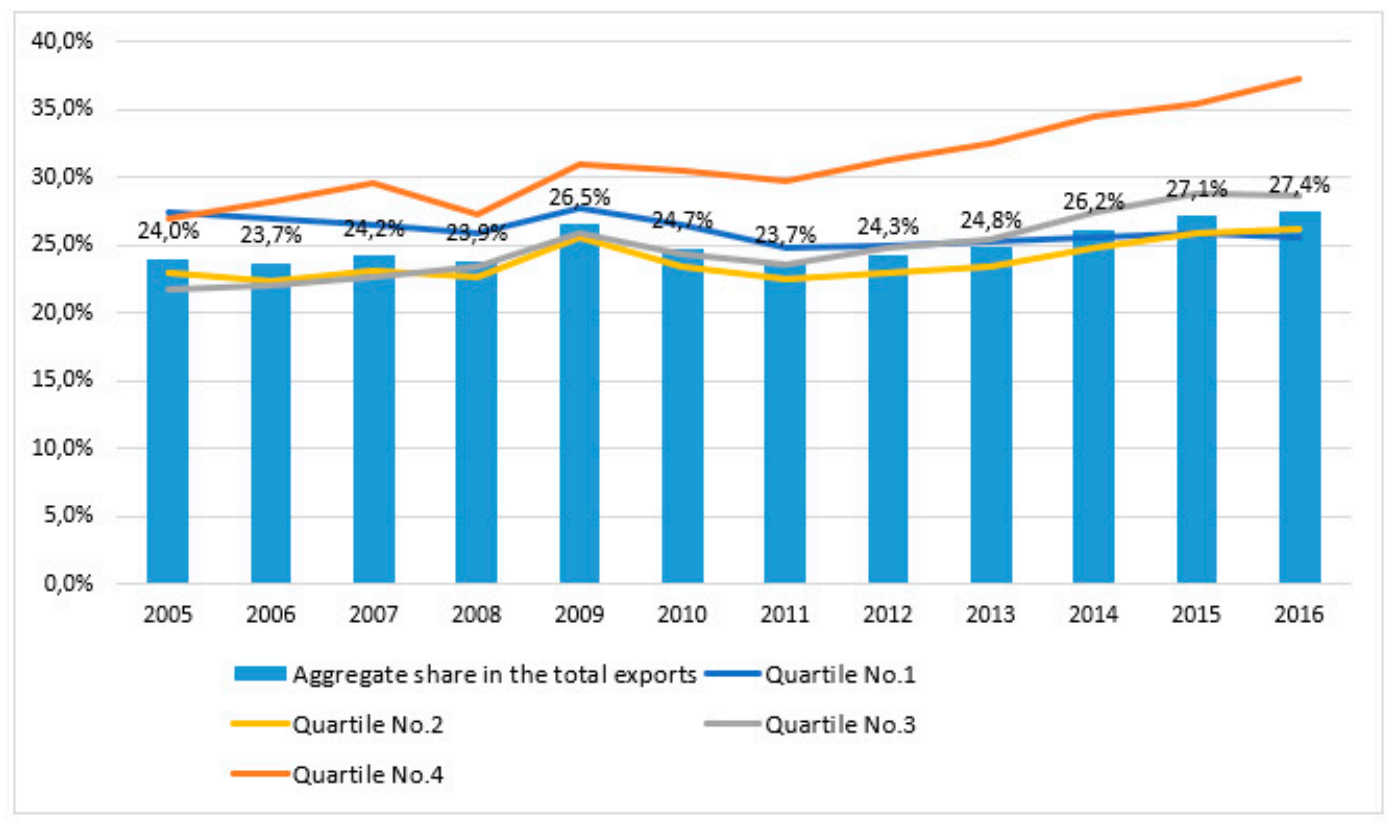

Figure 3. Share of Services in European Exports in the period of 2005-2016. Data compiled by the authors based on data from the International Trade Centre UNCTAD/WTO [36], from the respective countries.

The share of services in exports in European countries in 2005 was $24.0 \%$. In 2016, the share of services in the exports of these countries grew by 3.4 percentage points and amounted to $27.4 \%$. In 25 or $65.8 \%$ of the 38 countries considered, the share of services in exports increased. Respectively, in 13 or $34.2 \%$ of the considered countries, the share of services in exports decreased.

In 2005, the share of services in the exports of the countries considered was in the range of 10.7-76.1; thus, the variation range amounted to 65.4 percentage points. In 2016, the share of services in the exports of the countries considered constituted 9.7-88.0, with a variation range amounting to 78.4 percentage points.

To identify the differences in the tendencies of service export share change in total exports, we also considered the changes in the share of service exports by country groups within the four quartiles in descending order with respect to the rate of service export growth.

As shown in Figure 3, the share of services in exports in European countries in 2005 was 24.0\%. In 2016, the share of services in the exports of these countries grew by 3.4 percentage points and amounted to $27.4 \%$. Based on UNCTAD [6] data, we have calculated that the share of service exports in the general volume of exports in the world economy was $24.8 \%$ in 2016 . This means that the share of service exports in Europe was 2.6\% higher than in the rest world. In 25 of the 38 (or 65.8\%) countries considered, the share of services in exports increased. Respectively, in 13 or $34.2 \%$ of the countries considered the share of services in exports decreased.

In 2005, the share of services in the exports of the countries considered was in the range of 10.7-76.1; thus, the variation range amounted to 65.4 percentage points. In 2016, the share of services 
in the exports of the countries considered constituted 9.7-88.0, with a variation range amounting to 78.4 percentage points. Having considered the changes in the share of service exports in total exports in European countries, we make the following conclusions:

- The largest growth in the share of service exports and the highest value of the share of service exports in the period of 2005-2016 was demonstrated by the countries grouped into the fourth quartile. The fourth quartile includes many European countries with lower GDP per capita indicators. The tendency that we have identified contradicts the findings of Loungani et al. [5] that high service export figures are linked to higher GDP per capita indicators.

- In the period of 2005-2016, in European countries the share of service exports in total exports increased from $24 \%$ to $27.4 \%$, which corresponds to the findings of numerous researchers regarding service export share growth in international trade $[3-5,9]$.

- In the period of 2005-2016, the variation range of the share of service exports in the total exports of different European countries increased by 13.0 percentage points, which is evidence of the growing heterogeneity between the export structure of service exports and goods exports in European countries.

- Despite the presence of a common tendency of service export share growth in European countries, a range of countries that had the highest share of service exports in 2005 displayed a decrease in the share of service exports in total exports in 2016. Firstly, this fact may indicate the growing heterogeneity between the export structure of service exports and goods exports in different European countries. Secondly, it indicates that in specific periods, changes in the share of service exports in different countries are influenced not only by common factors (or the different effects these factors have), such as development of new technologies, but also by other factors that may vary from country to country. For instance, in the opinion of Loungani et al. [5], a country's experience in providing export services depends not only on its development stage and income level, but also on its geographical location in a specific region.

\subsection{Are Leaders in Service Export Growth Rate Also Innovation Leaders?}

In this subsection, we consider whether there is certain dependence between the levels of innovative development of a country and its service export growth rates. A comparison was made for four groups of countries grouped by quartiles. Thus, we determined the quartiles that comprise countries categorized as "Innovation Leaders" according to the classification of the European Innovation Scoreboard [38]. According to the European Innovation Scoreboard [38], in total, there are seven European countries that are categorized as "Innovation Leaders". One of these countries-Switzerland - was not included in the present research due to a lack of available data on service exports. None of the six remaining countries-Sweden, Denmark, Finland, the Netherlands, the United Kingdom, and Germany-were grouped into the fourth quartile, and only one country was grouped into the third quartile. Three countries were grouped into the second quartile and one country was grouped into the first quartile. The data obtained allowed us to conclude that European countries categorized as "Innovation Leaders" in accordance with the European Innovation Scoreboard [38] are not the leading countries in Europe with regard to the rates of service export growth. For example, the country with the highest rank among "Innovation Leaders" in Europe-Switzerland—only takes up the sixteenth position in the ranking of countries in terms of service export growth rates. Therefore, we may conclude that in Europe, categorizing a country into the group of "Innovation Leaders" according to the European Innovation Scoreboard [37] is not the determining factor of ensuring the highest rates of service export growth.

To determine the differences in average growth in service exports in each of the four "innovator" groups, we conducted a dispersion analysis. 30 European countries were categorized into four groups: "Innovation Leaders", "Strong Innovators", "Moderate Innovators", and "Modest Innovators" according to the classification of the European Innovation Scoreboard [38]. The conducted dispersion analysis showed that the countries categorized into the group "Innovation Leaders" demonstrated 
an average growth in service exports amounting to $57.42 \%$ in 2016 compared to 2005 . This indicator was equal to $90.21 \%$ in the group "Strong Innovators", $74.18 \%$ in the group "Moderate Innovators", and $61.96 \%$ in the group "Modest Innovators" (see Appendix D, and Figure 4). The results of the analysis of variance (ANOVA) reveal that in the period of 2005-2016 European countries categorized in the group "Innovation Leaders" demonstrated the lowest service export growth.

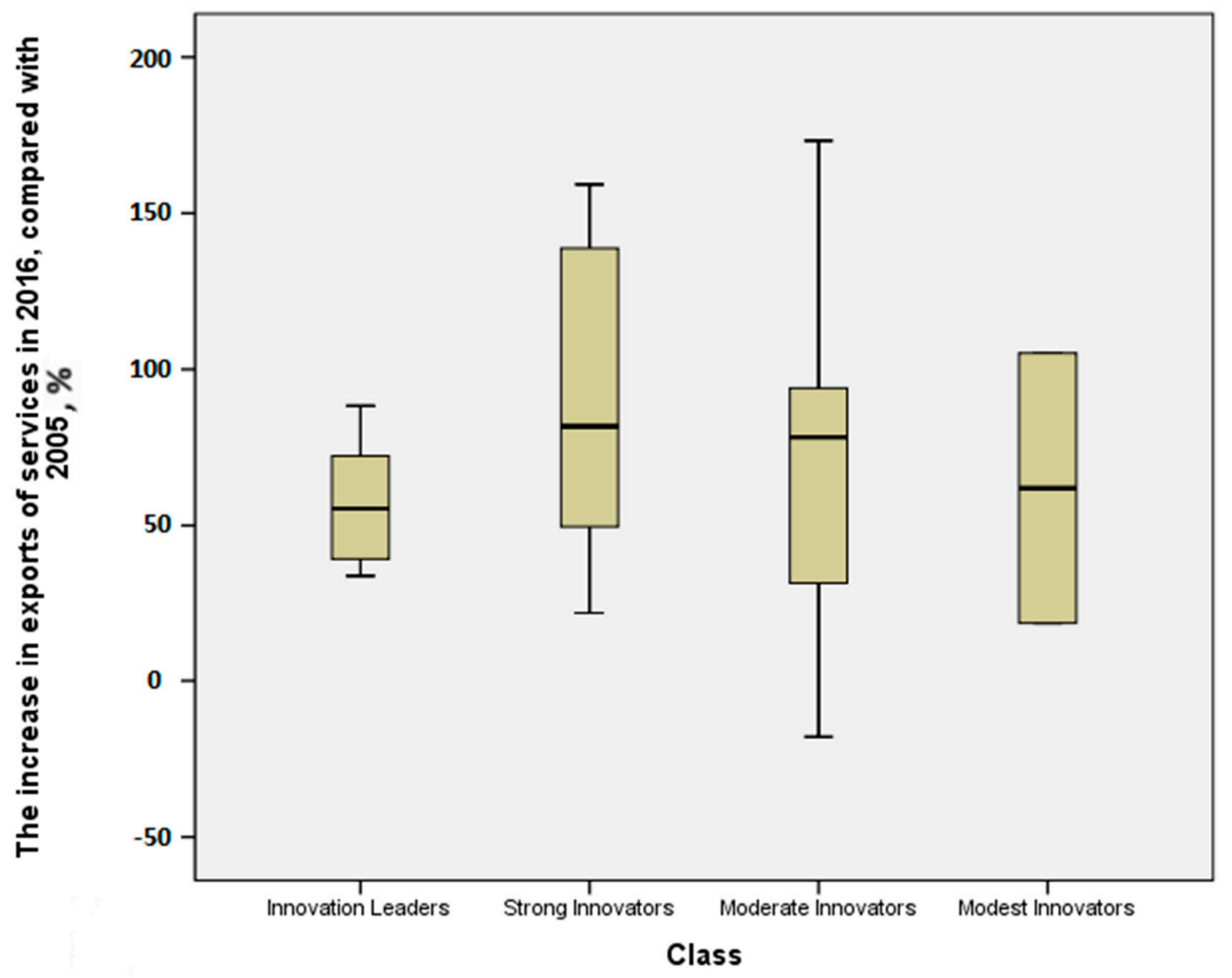

Figure 4. Box plot of service export growth in the period of 2005-2016.

The data we obtained does not correlate with the findings of Rodriguez et al. [29]. Perhaps, this contradiction between ours and their results may be explained by the specifics of concrete countries or a concrete region, as pointed out by Loungani et al. [5]. We believe that these specifics may include a low initial level of the share of service exports in 2005 in the countries outside the "Innovation Leaders" category, which, in its turn, ensured high service export growth rates in these countries. Furthermore, the export of services is steadily more popular strategy of firms (including SMEs) in emerging economy countries [40]. The presence of firms from emerging markets in the foreign markets increased during the last twenty years. Moreover, multinational companies discovered sourcing opportunities in emerging economies where labor force has high levels of general and specific human capital; in the same time wage level and tax regimes make outsourcing highly profitable [41-43]. Over time, the competence of firms in emerging markets increased, and prices for their services increased as well. The growth rate of wage level in emerging economies of Europe is higher than the growth rate of wage level in developed economies [44]. The development of information and communication technologies that allow quick and cheap transfer of services also contributed to significant increase of service exports from emerging economies [45,46]. Moreover, Aidukienè and Kazlauskienè [9] point out certain differences and specifics of service exports that may appear depending on the amount of added value. Thus, we assume that European countries outside the "Innovation Leaders" category, demonstrating high rates of service export growth from 2005 to 2016, mainly exported services with low added value that do not require considerable investment in R\&D and a high level of innovation development. 


\subsection{Sensitivity of Service Exports to Financial Crises}

In this subsection, we consider the changes in the volume of service exports and goods exports in Europe during the financial crisis of 2008-2009. In 2008, the volume of service exports compared to 2005-2007 reached its maximum values. In 2009, service exports in comparison with 2008 decreased by $13.1 \%$. But in 2010, service exports already started to grow and in 2011 they exceeded the indicators for 2008 by $1.8 \%$. In 2014, service exports surpassed the indicator for 2008 by $17.8 \%$. In the period of 2005-2008, the volume of goods exports, similarly to service exports, reached its maximum value in 2008 (Figure 5).

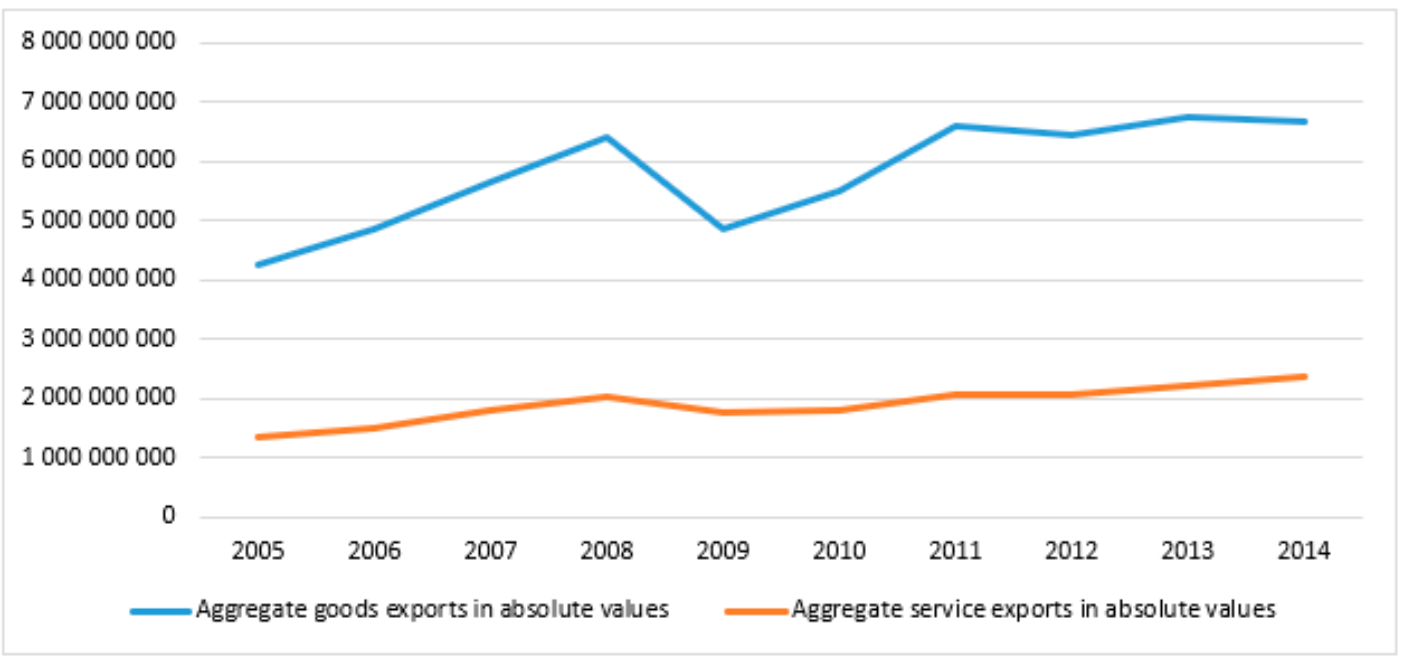

Figure 5. Changes in the share of service exports and goods exports in Europe in 2005-2014. Data compiled by the authors based on data from the International Trade Centre UNCTAD/WTO [36] from the respective countries.

However, the drop in goods exports was more pronounced; it amounted to $25.1 \%$. That is, the decrease in goods exports was 1.9 times higher than the decrease in service exports. In 2014, goods exports exceeded the indicator for 2008 by $3.3 \%$. This is 14.5 percentage points lower than the increase in service export growth in the same period. Having compared the data obtained on the scale of the drop and the rates of consequent growth in service exports and goods exports, we may conclude that service exports in Europe are less sensitive to adverse macroeconomic effects. The data we obtained correlate with the findings of Borchert and Mattoo [32], Ariu [10], and Loungani et al. [5] that service exports are more resistant to crises and financial shocks rather than goods exports.

\section{Conclusions}

In the present research, we have considered the changes that occurred in service exports in European countries in the period of 2005-2016. We have discovered that in this period, European countries experienced considerable changes in a range of indicators and tendencies characteristic of service exports. One of these tendencies is prominent growth in service exports in relation to growth in goods exports, and correspondingly, growth in the share of service exports in total exports. From 2005 to 2016, service exports in European countries increased by $60.1 \%$. In the same period, goods exports increased by $33.7 \%$. However, the trend of the share service exports growth in the general volume of export is not common for all European countries but only for $65.8 \%$ of the countries explored in this study.

In the period of 2005-2016, in European countries, the share of service exports in total exports, increased from $24 \%$ to $27.4 \%$. We have calculated that the share of service exports in the European countries in 2016 was $2.6 \%$ higher than the share of service exports in the world. 
We have also discovered that the trend of growth in the share of service exports in total exports is in line with the tendency of growth in the share of service exports in GDP. The rates of growth in the share of service exports in GDP in the considered European countries were higher, amounting to 33.3\% compared to the rates of growth in the share of service exports in total exports, which constituted $14.2 \%$.

In the considered period, in different European countries, the heterogeneity of export structure between service exports and goods exports grew by 13 percentage points, which might be the evidence of changes and/or an increase in the number of factors with an impact on the development of service exports in different countries.

We have also found that there is a strong positive correlation between high service export growth rates and high GDP growth rates and between high service export growth rates and high GDP per capita growth rates. The conducted regression analysis demonstrates that growth in GDP of $1 \%$ on average corresponds to the growth in service exports of $1.96 \%$. It follows from the regression equation that an increase in the GDP per capita growth rate of $1 \%$ corresponds to average growth in service exports of $1.704 \%$. This finding confirms the conclusions of the previous studies arguing that the growth of service sector exports is associated with income growth [2,47].

At the same time, using the analysis of variance (ANOVA), we have established that categorizing a country in the group of "Innovation Leaders" according to the European Innovation Scoreboard [38] classification does not guarantee higher rates of service export growth. This finding is in line with some previous studies that explored service exports in the Scandinavian countries considered as innovation leaders in Europe [48]. Furthermore, we have presented evidence that shows that service exports are less sensitive to adverse macroeconomic effects than goods exports.

Further research might extend the analysis of service exports to other geographical contexts. Subsequent studies could explore changes in service exports in various industries in Europe and elsewhere. Future research can also include the time trend in the regression model and run multivariate data analysis, (We are thankful to an anonymous reviewer for this suggestion).

Author Contributions: Both authors contributed significantly to the completion of this manuscript. A.P. designed the concept of the paper, wrote the main part of the literature review, and collected and analyzed the data. M.S. contributed to the theoretical review, conclusions and limitations of the study.

Funding: This paper is an output of a scientific project supported by RISEBA University.

Acknowledgments: Insightful comments from the anonymous reviewers as well as Sajid Anwar are warmly appreciated. The authors would like to thank Dmitry Pavlyuk, Levs Fainglozs, and Kateryna Romanovska for their assistance with the statistical analysis.

Conflicts of Interest: The authors declare no conflicts of interest.

\section{Appendix A}

Table A1. Grouping into quartiles according to growth rate (services).

\begin{tabular}{|c|c|c|c|c|}
\hline Quartile & Exporters & Exported Value in 2005 & Exported Value in 2016 & Growth (Services) \\
\hline \multirow{9}{*}{ 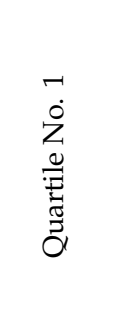 } & Greece & $33,866,066$ & $27,776,549$ & $-18.0 \%$ \\
\hline & Italy & $92,048,765$ & $101,402,280$ & $10.2 \%$ \\
\hline & Ukraine & $10,442,000$ & $12,394,000$ & $18.7 \%$ \\
\hline & Norway & $29,834,200$ & $36,404,198$ & $22.0 \%$ \\
\hline & Slovakia & $6,401,922$ & $8,323,309$ & $30.0 \%$ \\
\hline & Croatia & $10,253,355$ & $13,490,284$ & $31.6 \%$ \\
\hline & Denmark & $43,860,601$ & $58,690,526$ & $33.8 \%$ \\
\hline & Turkey & $27,822,000$ & $37,634,000$ & $35.3 \%$ \\
\hline & Spain & $92,173,960$ & $127,132,063$ & $37.9 \%$ \\
\hline
\end{tabular}


Table A1. Cont.

\begin{tabular}{|c|c|c|c|c|}
\hline Quartile & Exporters & Exported Value in 2005 & Exported Value in 2016 & Growth (Services) \\
\hline \multirow{10}{*}{ 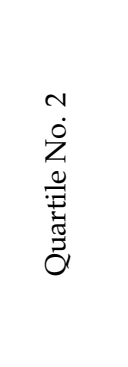 } & United Kingdom & $234,931,927$ & $327,176,156$ & $39.3 \%$ \\
\hline & Finland & $18,200,199$ & $25,438,747$ & $39.8 \%$ \\
\hline & Austria & $41,461,506$ & $60,020,130$ & $44.8 \%$ \\
\hline & France & $153,263,922$ & $236,760,408$ & $54.5 \%$ \\
\hline & Germany & $159,418,270$ & $272,737,619$ & $71.1 \%$ \\
\hline & Bosnia and Herzegovina & 988,951 & $1,702,452$ & $72.1 \%$ \\
\hline & Switzerland & $66,381,423$ & $114,356,199$ & $72.3 \%$ \\
\hline & Russia & $28,845,400$ & $50,503,970$ & $75.1 \%$ \\
\hline & Estonia & $3,472,735$ & $6,108,284$ & $75.9 \%$ \\
\hline & Slovenia & $4,094,295$ & $7,209,640$ & $76.1 \%$ \\
\hline \multirow{10}{*}{ 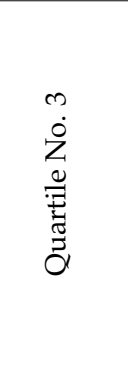 } & Czech Republic & $13,151,352$ & $23,758,998$ & $80.7 \%$ \\
\hline & Hungary & $12,642,272$ & $23,079,323$ & $82.6 \%$ \\
\hline & Belgium & $59,226,400$ & $111,017,375$ & $87.4 \%$ \\
\hline & Sweden & $38,113,509$ & $71,772,861$ & $88.3 \%$ \\
\hline & Latvia & $2,467,620$ & $4,695,824$ & $90.3 \%$ \\
\hline & Portugal & $15,101,658$ & $29,296,898$ & $94.0 \%$ \\
\hline & Romania & $9,668,077$ & $19,840,892$ & $105.2 \%$ \\
\hline & Albania & $1,266,650$ & $2,650,802$ & $109.3 \%$ \\
\hline & Luxembourg & $40,416,283$ & $94,579,479$ & $134.0 \%$ \\
\hline & Moldova & 446,120 & $1,047,110$ & $134.7 \%$ \\
\hline \multirow{9}{*}{ 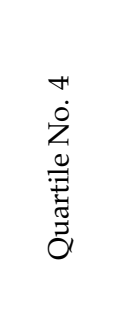 } & Iceland & 2,220,295 & $5,409,266$ & $143.6 \%$ \\
\hline & Lithuania & $3,039,493$ & $7,444,949$ & $144.9 \%$ \\
\hline & Ireland & $56,579,181$ & $146,677,640$ & $159.2 \%$ \\
\hline & Poland & $18,156,555$ & $49,010,245$ & $169.9 \%$ \\
\hline & Malta & $4,153,922$ & $11,351,487$ & $173.3 \%$ \\
\hline & Belarus & $2,342,300$ & $6,812,900$ & $190.9 \%$ \\
\hline & Armenia & 430,150 & $1,609,997$ & $274.3 \%$ \\
\hline & Georgia & 737,902 & $3,366,636$ & $356.2 \%$ \\
\hline & Azerbaijan & 741,460 & $4,374,597$ & $490.0 \%$ \\
\hline
\end{tabular}

\section{Appendix B}

Table A2. Grouping into quartiles according to growth rate (products).

\begin{tabular}{|c|c|c|c|c|}
\hline Quartile & Exporters & Exported Value in 2005 & Exported Value in 2016 & Growth (Products) \\
\hline \multirow{9}{*}{ 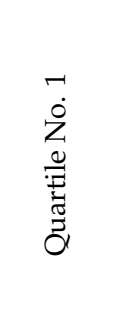 } & Norway & $29,834,200$ & $36,404,198$ & $-13.6 \%$ \\
\hline & Finland & $18,200,199$ & $25,438,747$ & $-12.1 \%$ \\
\hline & Luxembourg & $40,416,283$ & $94,579,479$ & $1.0 \%$ \\
\hline & United Kingdom & $234,931,927$ & $327,176,156$ & $4.8 \%$ \\
\hline & Sweden & $38,113,509$ & $71,772,861$ & $7.2 \%$ \\
\hline & Ukraine & $10,442,000$ & $12,394,000$ & $10.5 \%$ \\
\hline & France & $153,263,922$ & $236,760,408$ & $12.6 \%$ \\
\hline & Denmark & $43,860,601$ & $58,690,526$ & $14.7 \%$ \\
\hline & Ireland & $56,579,181$ & $146,677,640$ & $17.6 \%$ \\
\hline \multirow{10}{*}{ 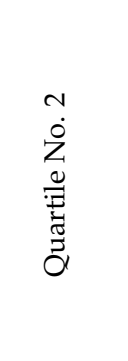 } & Russia & $28,845,400$ & $50,503,970$ & $18.2 \%$ \\
\hline & Belgium & $59,226,400$ & $111,017,375$ & $18.6 \%$ \\
\hline & Italy & $92,048,765$ & $101,402,280$ & $23.7 \%$ \\
\hline & Austria & $41,461,506$ & $60,020,130$ & $29.3 \%$ \\
\hline & Germany & $159,418,270$ & $272,737,619$ & $37.2 \%$ \\
\hline & Iceland & $2,220,295$ & $5,409,266$ & $44.0 \%$ \\
\hline & Portugal & $15,101,658$ & $29,296,898$ & $44.0 \%$ \\
\hline & Spain & $92,173,960$ & $127,132,063$ & $46.2 \%$ \\
\hline & Belarus & $2,342,300$ & $6,812,900$ & $47.3 \%$ \\
\hline & Croatia & $10,253,355$ & $13,490,284$ & $55.6 \%$ \\
\hline
\end{tabular}


Table A2. Cont.

\begin{tabular}{|c|c|c|c|c|}
\hline Quartile & Exporters & Exported Value in 2005 & Exported Value in 2016 & Growth (Products) \\
\hline \multirow{10}{*}{ 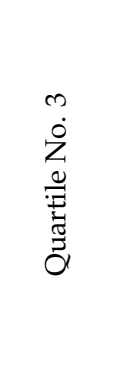 } & Greece & $33,866,066$ & $27,776,549$ & $59.5 \%$ \\
\hline & Hungary & $12,642,272$ & $23,079,323$ & $65.5 \%$ \\
\hline & Malta & $4,153,922$ & $11,351,487$ & $66.2 \%$ \\
\hline & Estonia & $3,472,735$ & $6,108,284$ & $69.4 \%$ \\
\hline & Slovenia & $4,094,295$ & $7,209,640$ & $83.7 \%$ \\
\hline & Moldova & 446,120 & $1,047,110$ & $87.4 \%$ \\
\hline & Armenia & 430,150 & $1,609,997$ & $92.9 \%$ \\
\hline & Turkey & $27,822,000$ & $37,634,000$ & $94.0 \%$ \\
\hline & Czech Republic & $13,151,352$ & $23,758,998$ & $106.2 \%$ \\
\hline & Lithuania & $3,039,493$ & $7,444,949$ & $107.3 \%$ \\
\hline \multirow{9}{*}{ 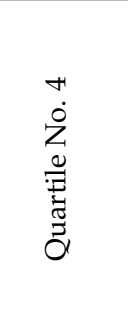 } & Azerbaijan & 741,460 & $4,374,597$ & $108.6 \%$ \\
\hline & Latvia & $2,467,620$ & $4,695,824$ & $115.6 \%$ \\
\hline & Poland & $18,156,555$ & $49,010,245$ & $119.8 \%$ \\
\hline & Bosnia and Herzegovina & 988,951 & $1,702,452$ & $123.0 \%$ \\
\hline & Romania & $9,668,077$ & $19,840,892$ & $129.3 \%$ \\
\hline & Switzerland & $66,381,423$ & $114,356,199$ & $132.7 \%$ \\
\hline & Slovakia & $6,401,922$ & $8,323,309$ & $143.5 \%$ \\
\hline & Georgia & 737,902 & $3,366,636$ & $144.2 \%$ \\
\hline & Albania & $1,266,650$ & $2,650,802$ & $198.1 \%$ \\
\hline
\end{tabular}

\section{Appendix C}

Table A3. Results of regression analysis estimating the relationship between GDP growth rate, GDP per capita growth rate and service exports growth between 2005 and 2016.

\begin{tabular}{ccc}
\hline & $\begin{array}{c}\text { The Growth Rate of the GDP } \\
\text { in 2016 Compared with 2005 }\end{array}$ & $\begin{array}{c}\text { The Growth Rate of the GDP per } \\
\text { Capita in 2016 Compared with 2005 }\end{array}$ \\
\hline Standardized Coefficients Beta & $0.822^{* * * *}$ & 0.759 *** \\
Unstandardized Coefficients B & 1.916 & 1.704 \\
Intercept & 0.160 & 0.303 \\
$\mathrm{R}^{2}$ & 0.675 & 0.576 \\
Adjusted $\mathrm{R}^{2}$ & 0.67 & 0.56 \\
F value & 74.76 & 48.83 \\
Sig. F change & 0.00 & 0.00 \\
\hline
\end{tabular}

Notes: Standardized beta regression coefficients. ${ }^{*} p<0.05 ;{ }^{* *} p<0.01{ }^{* * *} p<0.001$.

\section{Appendix D}

Table A4. Results of the dispersion analysis related to service exports growth during 2016 compared to 2005 in different groups of innovative countries.

\begin{tabular}{|c|c|c|c|c|c|c|c|c|c|}
\hline & \multirow{2}{*}{$\mathbf{N}$} & \multirow{2}{*}{ Mean } & \multirow{2}{*}{$\begin{array}{c}\text { Std. } \\
\text { Deviation }\end{array}$} & \multirow{2}{*}{$\begin{array}{l}\text { Std. } \\
\text { Error }\end{array}$} & \multicolumn{2}{|c|}{$95 \%$ Confidence Interval for Mean } & \multirow{2}{*}{ Minimum } & \multirow{2}{*}{ Maximum } & \multirow{2}{*}{$\begin{array}{c}\text { Between-Component } \\
\text { Variance }\end{array}$} \\
\hline & & & & & Lower Bound & Upper Bound & & & \\
\hline Innovation Leaders & 6 & 0.5742 & 0.22628 & 0.09238 & 0.33673 & 0.81166 & 0.338115 & 0.883134 & - \\
\hline Strong Innovators & 8 & 0.9021 & 0.50337 & 0.17797 & 0.48127 & 1.3229 & 0.220217 & 1.592431 & - \\
\hline Moderate Innovators & 14 & 0.7418 & 0.5814 & 0.1554 & 0.4061 & 1.0775 & -0.179812 & 1.732715 & - \\
\hline Modest Innovators & 2 & 0.6196 & 0.61184 & 0.4326 & -4.8776 & 6.1167 & 0.186937 & 1.052207 & - \\
\hline Total & 30 & 0.74287 & 0.49837 & 0.09099 & 0.55678 & 0.92897 & -0.179812 & 1.732715 & - \\
\hline Model & - & - & 0.51137 & 0.09336 & 0.55096 & 0.93478 & - & - & - \\
\hline Fixed Effects & - & - & - & 0.09336 & 0.44575 & 1.03999 & - & - & - \\
\hline Random Effects & - & - & - & - & - & - & - & - & -0.0190 \\
\hline
\end{tabular}

\section{References}

1. Uppenberg, K.; Strauss, H. Innovation and Productivity Growth in the EU Services Sector; European Investment Bank: Luxembourg. 2010. Available online: http://www.eib.org/attachments/efs/efs_ innovation_and_productivity_en.pdf (accessed on 11 March 2018).

2. Wirtz, J.; Tuzovic, S.; Ehret, M. Global business services: Increasing specialization and integration of the world economy as drivers of economic growth. J. Serv. Manag. 2015, 26, 565-587. [CrossRef] 
3. Mattoo, A.; Stern, R.; Zanini, G. A Handbook of International Trade in Services; Oxford University Press: Oxford, UK, 2008.

4. Gallagher, K. ICTSD Policy Paper on Trade in Services and Sustainable Development. 2008. Available online: https:/ / www.ictsd.org/downloads/2008/06/gallagher.pdf (accessed on 12 February 2018).

5. Loungani, P.; Mishra, S.; Papageorgiou, C.; Wang, K. World Trade in Services: Evidence from a New Dataset; IMF Working Paper, WP/17/77; International Monetary Fund: Washington, DC, USA, 2017.

6. UNCTAD. The Role of the Services Economy and Trade in Structural Transformation and Inclusive Development. 2017. Available online: http://unctad.org/meetings/en/SessionalDocuments/c1mem4d14_ en.pdf (accessed on 17 February 2018).

7. UNCTAD. Exports of Services and Economic Growth in Developing Countries. United Nations Conference on Trade and Development. 2004. Available online: http://unctad.org/en/docs/ditctncdmisc20036_en.pdf (accessed on 1 March 2018).

8. Mishra, S.; Lundstrom, S.; Anand, R. Service Export Sophistication and Economic Growth; Policy Research Working Paper; The World Bank: Washington, DC, USA, 2011. Available online: http:/ / siteresources.worldbank.org/ INTRANETTRADE/Resources/Internal-Training/287823-1285275962946/Service_Export_Growth.pdf (accessed on 10 March 2018).

9. Aidukienè, L.; Kazlauskienè, V. International Trade in Services: Development Trends and Possibilities. Econ. Manag. 2012, 17, 1315-1320. [CrossRef]

10. Ariu, A. Crisis-proof services: Why trade in services did not suffer during the 2008-2009 collapse. J. Int. Econ. 2016, 98, 138-149. [CrossRef]

11. Hufbauer, G.; Jensen, J.; Stephenson, S. Framework for the International Services Agreement; Policy Brief Number PB12-10; Peterson Institute for International Economics: Washington, DC, USA, 2012. Available online: https:/ / piie.com/publications / pb/pb12-10.pdf (accessed on 11 March 2018).

12. Felipe, L.; León-Ledesma, M.; Lanzafame, M.; Estrada, G. Sectoral engines of growth in developing Asia: Stylised facts and implications. Malays. J. Econ. Stud. 2009, 46, 107-133.

13. European Services Forum. International Services Trade \& Investment. 2012. Available online: http:/ / www. learneurope.eu/files/9413/7483/7529/ESF-_Servicies_facts_and_figures_en.pdf (accessed on 14 March 2018).

14. Starkevičiūtè, M. Lietuvos ekonominès integracijos gairès. Intelekt. Èkon. 2007, 1, 82-86.

15. Holtgrewe, U. Services Research along the Service Process: An Overview Study to Support UNI Europa's Services Policy Project; Report; Independent Research Institute; FORBA: Vienna, Austria, 2015. Available online: http:/ / www.uni-europa.org/wp-content/uploads/2016/06/2015-11-25-Service-Research-Report. pdf (accessed on 21 March 2018).

16. Gallego, J.; Rubalcaba, L.; Hipp, C. Services and organisational innovation: The right mix for value creation. Manag. Decis. 2013, 51, 1117-1134. [CrossRef]

17. Gervais, A.; Jensen, B. The Tradability of Services; Discussion Paper; NBER: Washington, DC, USA, 2014.

18. Leo, P.Y.; Philippe, J. International Service Tradability: Understanding Offshoring of Services. In Latin America's Emergence in Global Services: A New Driver of Structural Change in the Region? UN ECLAC: Santiago, Chile, 2014; pp. 39-57.

19. Rodrik, D. Premature Deindustrialization; NBER Working Paper No. 20935; NBER: Cambridge, MA, USA, 2015.

20. Francois, J.; Hoekman, B. Services trade and policy. J. Econ. Lit. 2010, 48, 642-692. [CrossRef]

21. Ariu, A. Services Versus Goods Trade: Are They the Same? Working Paper Research 237; National Bank of Belgium: Brussels, Belgium, 2012.

22. Breinlich, H.; Criscuolo, C. International trade in services: A portrait of importers and exporters. J. Int. Econ. 2011, 84, 188-206. [CrossRef]

23. World Trade Organization (WTO). International Trade Statistics. 2015. Available online: https://www.wto. org/english/res_e/statis_e/its2015_e/its2015_e.pdf (accessed on 14 March 2018).

24. Besedeš, T.; Prusa, T.J. The role of extensive and intensive margins and export growth. J. Dev. Econ. 2011, 96, 371-379. [CrossRef]

25. Dash, S. Fragmentation in International Trade: Manufacturing vs Services. 2005. Available online: https: / / papers.ssrn.com/sol3/papers.cfm?abstract_id=921328 (accessed on 19 January 2018).

26. Ghani, E.; Kharas, H. The Service Revolution. In Economic Premise; World Bank: Washington, DC, USA, 2010; Volume 14, pp. 1-5. Available online: https:/ / openknowledge.worldbank.org/handle/10986/10187 (accessed on 15 March 2018). 
27. Haksever, C.; Render, B.; Russell, R.S.; Murdick, R.G. Service Management and Operations, 2nd ed.; Prentice Hall: Upper Saddle River, NJ, USA, 2000.

28. Hoekman, B.; Mattoo, A. Services Trade and Growth, The World Bank Policy Research Working Paper No. 4461. 2008. Available online: http:/ / documents.worldbank.org/curated/en/117601468178449072/pdf/ wps4461.pdf (accessed on 17 March 2018).

29. Rodríguez, M.; Melikhova, Y.; Camacho, J. Trade in Services in the Baltic States: Evolution and Future Prospects. Technol. Econ. Dev. Econ. 2018, 24, 585-599. [CrossRef]

30. Gallouj, F.; Weber, M.; Stare, M.; Rubalcaba, L. The futures of the service economy in Europe: A foresight analysis. Technol. Forecast. Soc. Chang. 2015, 94, 80-96. [CrossRef]

31. Alaveras, G.; Martens, B. International Trade in Online Services; Institute for Prospective Technological Studies Digital Economy Working Paper; European Commission: Brussels, Belgium, 2015.

32. Borchert, I.; Mattoo, A. The crisis-resilience of services trade. Serv. Ind. J. 2009, 30, 2115-2136. [CrossRef]

33. Francois, J.; Woerz, J. Follow the bouncing ball-Trade and the great recession redux. In The Great Trade Collapse: Causes, Consequences and Prospects; Baldwin, R.E., Ed.; A CEPR: London, UK, 2009; pp. 87-94.

34. Chor, D.; Manova, K. Off the cliff and back? Credit conditions and international trade during the global financial crisis. J. Int. Econ. 2012, 87, 117-133. [CrossRef]

35. European Union. EUROPA-Countries/European Union. 2018. Available online: https://europa.eu/europeanunion/about-eu/countries_en (accessed on 4 March 2018).

36. International Trade Centre UNCTAD/WTO. Trade Map, Market Analysis and Research, 2017. Available online: https: / www.trademap.org/Index.aspx (accessed on 14 March 2018).

37. United Nations. World Economic Situation and Prospects: Country Classification. 2014. Available online: http:/ / www.un.org/en/development/desa/policy/wesp/wesp_current/2014wesp_country_classification.pdf (accessed on 10 March 2018).

38. European Commission. European Innovation Scoreboard. 2016. Available online: http://ec.europa.eu/ growth/industry/innovation/facts-figures/scoreboards_en (accessed on 4 March 2018).

39. International Monetary Fund. GDP Per Capita; International Monetary Fund: Washington, DC, USA, 2017. Available online: http://www.imf.org/external/datamapper/NGDPDPC@WEO/OEMDC/ADVEC/ WEOWORLD (accessed on 2 March 2018).

40. Aulakh, P.S.; Rotate, M.; Teegen, H. Export strategies and performance of firms from emerging economies: Evidence from Brazil, Chile, and Mexico. Acad. Manag. J. 2000, 43, 342-361.

41. Garten, J.E. The Big Ten: The Big Emerging Markets and How They Will Change Our Lives; Basic Books: New York, NY, USA, 1997.

42. Solesvik, M.Z.; Westhead, P. Partner selection for strategic alliances: Case study insights from the maritime industry. Ind. Manag. Data Syst. 2010, 110, 841-860. [CrossRef]

43. Solesvik, M.; Gulbrandsen, M. Interaction for Innovation: Comparing Norwegian Regions. J. Entrep. Manag. Innov. (JEMI) 2014, 10, 7-28.

44. Statista. Development of Real Wages in the Member States of the European Union in 2017 (Compared to the Previous Year). Available online: https:/ / www.statista.com/statistics/264605/development-of-real-wagesin-eu-countries / (accessed on 10 March 2018).

45. Freund, C.; Weinhold, D. The Internet and international trade in services. Am. Econ. Rev. 2002, 92, $236-240$. [CrossRef]

46. Wren, A. (Ed.) The Political Economy of the Service Transition; Oxford University Press: Oxford, UK, 2013.

47. Francois, J.; Reinert, K. The role of services in the structure of production and trade: stylized facts from a cross-country analysis. Asia-Pac. Econ. Rev. 1996, 2, 35-43.

48. Solesvik, M.Z. The Triple Helix model for regional development and innovation: Context of Nordic countries. Forum Scientiae Oeconomia 2017, 5, 5-21.

(C) 2018 by the authors. Licensee MDPI, Basel, Switzerland. This article is an open access article distributed under the terms and conditions of the Creative Commons Attribution (CC BY) license (http:/ / creativecommons.org/licenses/by/4.0/). 